\title{
Anti-infective Assessment of Dichrostachys cinerea Root Bark, an Ivorian Anti-asthmatic Herbal
}

\author{
N'Guessan-Irie Amenan Geneviève $e^{1, *}$, Zinzendorf Nanga Yessé2, \\ Djatchi Richmond Anderson ${ }^{2}$, Kablan Landry ${ }^{3,4}$, Kouakou Sylvain Landry, \\ Aka Agnimou Léon ${ }^{5}$, Djobo Adjé Wilfried ${ }^{5}$ \\ ${ }^{1}$ Laboratory of Pharmacology, Training and Research Unit of Pharmaceutical and Biological Sciences, \\ Felix Houphouet-Boigny University, Côte d'Ivoire \\ ${ }^{2}$ Laboratory of Bacteriology and Virology, Training and Research Unit of Pharmaceutical and Biological Sciences, \\ Felix Houphouet-Boigny University, Côte d'Ivoire \\ ${ }^{3}$ Péléforo Gon Coulibaly University of Korhogo, Côte d'Ivoire \\ ${ }^{4}$ UMR CNRS 8076 BioCIS, Châtenay-Malabry, France \\ ${ }^{5}$ Training and Research Unit of Pharmaceutical and Biological Sciences, Felix Houphouet-Boigny University, Côte d'Ivoire
}

Copyright $\bigcirc 2018$ by authors, all rights reserved. Authors agree that this article remains permanently open access under the terms of the Creative Commons Attribution License 4.0 International License

\begin{abstract}
Dichrostachys cinerea root bark is used in Ivorian folk to manage asthma attack. As asthma is often accompanied with secondary infections, this study aimed to assess its potential effects of this medicine against microorganisms. An aqueous-alcoholic extract was obtained from Dichrostachys cinerea root bark. The growth of bacteria in the presence of the extract was measured by the method of dilution in microplate. The antiparasitic potent of the extract was determined on cell culture in microplate with determination of the parasitic viability by reading the optical density of wells in optical microscope. The antifungal activity of the extract was measured by the method of dilution in tube. At 200; 100; $50 ; 25 ; 12.5 ; 6.25$ and $3.125 \mathrm{mg} / \mathrm{mL}$ the extract did not inhibit growth of Staphylococcus aureus, Escherichia coli, Bacillus sp, Pseudomonas aeruginosa and Enterococcus faecalis. IC90 of the plant extract on Trypanosoma brucei brucei, Caenorhabditis elegans and Aspergillus fumigatus was superior to $125 \mu \mathrm{g} / \mathrm{mL}$ and on average $50 \mu \mathrm{g} / \mathrm{mL}$ on Leishmania donovani and Candida albicans. In conclusion, the extract did not exert any significant anti-infective effect towards the studied microorganisms, supposing that Dichrostachys cinerea root bark would be effective only to delete bronchospasm, the main characteristic of asthma attack.
\end{abstract}

Keywords Plant, Antibacterial, Antiparasitic, Antifungal

\section{Introduction}

The traditional medicine relieves more than $70 \%$ of the populations in the Third World [1] and 70 to $90 \%$ of the African populations [2]. Because of the cost very often raised of conventional medicine, associated with the increase of multi-resistant bacteria, it is noted a renewed interest for African traditional medicine [3-5]. Thus, it is essential to look for new bioactive substances stemming from the Traditional Pharmacopoeia, effective, broad spectrum anti-infective agents with a low cost. Root bark of Dichrostachys cinerea (L.) Wight \& Arn (Fabaceae) is used by Adioukrous peoples (South of Côte d'Ivoire), by trituration in some water, to treat asthma attacks [6]. A previous study [7] brought out the relaxing effect of a crude aqueous-alcoholic extract of Dichrostachys cinerea root bark in mice isolated trachea, that would justify the use of this part of the plant in the treatment of the bronchospasm during asthma. However, asthma is a chronic inflammatory airways disease of the bronchi [8] and is often accompanied with secondary infections. The current study aimed to assess potential effects of an aqueous-alcoholic extract, containing saponins, tannins, alkaloids and flavonoids [9], against microorganisms such bacteria, parasites and fungi.

\section{Materials and Methods}

\subsection{Plant Material}

Roots of Dichrostachys cinerea were collected in bushes near Grand-Bassam (South-East of Côte d'Ivoire) in January 2009 (for screening of antiparasitic and antifungal activities) and in April 2017 (for screening of antibacterial activity). The batches were authenticated by taxonomists at the Centre National de Floristique d'Abidjan, i.e. National 
Floristic Center of Abidjan (Côte d'Ivoire), in comparison with the voucher of the Centre's herbaria (Dichrotachys cinerea (L.) Wight \& Arn. Adjanohoun E. and Ake Assi L., 29, forest of Banco Ivory Coast on March 20, 1972). Bark was removed from the roots, washed with distilled water, air-dried at air-conditioning temperature for two weeks, and pulverized using an electric grinder (Retsch GM $300^{\circledR}$ ). The powder of root bark served as sample to be tested.

\subsection{Extraction Procedure}

The aqueous-alcoholic extract of Dichrostachys cinerea root bark was prepared with an ethanol-distilled water mixture (100 $\mathrm{g}$ dry powder material in $1 \mathrm{~L}$; room temperature, under magnetic stirring, 24 hours). After filtration twice on white cotton and once on whatman filter paper No 3, the extract was dried under reduced pressure at $45^{\circ} \mathrm{C}$ temperature using a rotary evaporator (Heidoph RZ 2.5 ). Extraction yield was $8.16 \%$. The extract powder was stored in a glass container covered with parafilm and kept in at $7-8{ }^{\circ} \mathrm{C}$ temperature.

\subsection{Chemicals \& Laboratory Materials}

- $\quad$ Sterile distilled water (IN HOUSE)

- Dimethyl sulfoxide "DMSO" (VWR, France)

- Sterile disks of blotting paper (PRATDUMAS, France)

- MOPS and RPMI media (SIGMA and GIBCO, France)

- Mueller Hinton agar (BIO-RAD, France)

- Mueller Hinton broth (HiMedia Laboratories, India)

- Disks of antibiotics (BIO-RAD, France)

- $\quad$ Petri dishes (MONOLAB S.N.C, Italy)

- $\quad$ Sterile test tubes (LAB-BOX, France)

- Microplates (DELTALAB, Spain)

- Densimeter "Reader of optical density" (DENSIMAT ${ }^{\circledR}$, BioMérieux, France)

- $\quad$ Optical microscope (OPTIKA ${ }^{\circledR}$, B-383 PLI, Italy)

- Cefixime "standard antibiotic" $\left(\mathrm{OROKEN}^{\circledR}\right.$, SANOFI, France)

- Melarsoprol "standard trypanocide drug" (ARSOBAL $^{\circledR}$, SANOFI-AVENTIS, France)

- Pentamidine "standard elephanticide drug" (PENTACARINAT $^{\circledR}$, SANOFI-AVENTIS, France)

- Mebendazole "standard anthelminthic drug" (VERMOX $^{\circledR}$, JANSSEN, Belgium)

- Amphotericin B "standard antifungal drug" (FUNGIZONE $^{\circledR}, \quad$ BRISTOL-MYERS SQUIBB, France)

\subsection{Tested Microorganisms}

\subsubsection{Bacteria}

- Staphylococcus aureus

- Escherichia coli
- $\quad$ Bacillus $s p$

- Pseudomonas aeruginosa

- Enterococcus faecalis

2.4.2. Parasites

- $\quad$ Trypanosoma brucei brucei

- Leishmania donovani

- Caenorhabditis elegans

\subsubsection{Fungi}

- Aspergillus fumigatus

- Candida albicans

\subsection{Anti-infective Potential Research}

\subsubsection{Antibacterial research}

Bacterial strains of human origin were provided by a Hospital and University Centre in Abidjan (Côte d'Ivoire), then transferred on Mueller Hinton agar in the Laboratory of Bacteriology and Virology, Training and Research Unit of Pharmaceutical and Biological Sciences, Felix Houphouet-Boigny University, the day before to obtain young bacterial colonies that were used to realize a suspension in $10 \mathrm{~mL}$ of broth sterile Mueller Hinton. The obtained suspension, that optical density was read with densimeter, was estimated in approximately $1.5 \times 10^{8}$ cells $/ \mathrm{mL}$ and constituted the dilution $10^{\circ}$ or the pure inoculum of every bacterial strain. The pure inoculum, as well as, dilutions in $10^{-4}, 10^{-3}, 10^{-2}$ and $10^{-1}$ cells $/ \mathrm{mL}$, were sowed on Mueller Hinton agar, then incubated in $37^{\circ} \mathrm{C}$ during 18 to 24 hours. Besides, concentrations of the extract in 200; $100 ; 50 ; 25 ; 12.5 ; 6.25$ and $3.125 \mathrm{mg} / \mathrm{mL}$ were extemporaneously prepared in sterile distilled water. Microplates of 96 wells were inoculated with various broth of bacteria, in presence of the various concentrations of the extract or the standard antibiotic (cefixime) or without any substance for the control. Inoculated microplates were covered with paraffin then arranged in a moistened tub to reduce the risks of dehydration of cupules. Incubation was carried out at $37{ }^{\circ} \mathrm{C}$ during 18 to 24 hours. The reading, made the next day, consisted in looking for a turbidity in every cupule, sign of a microbial growth and allowing to determine the minimal inhibitive concentration (MIC), i.e. the lowest concentration of a substance for that there is no visible bacterial growth in the naked eye after 18 to 24 hours incubation.

For the determination of the minimal bactericidal concentration $(\mathrm{MBC})$ i.e. the lowest concentration of substance that leaves less than $0.01 \%$ of germs alive, the contents of the cupules in which no turbidity was observed were sowed on a Mueller Hinton agar microplate by beginning with the tube MIC. After 24 hours incubation at $37^{\circ} \mathrm{C}$, the first cupule that number of germs was lower or equal to that of the bacteria broth at $10^{-4}$ cells $/ \mathrm{mL}$ corresponded to the $\mathrm{MBC}$.

About the antibiogram, sterile disks of blotting paper 
were soaked with the various concentrations of the extract as well as with cefixime in $20 \mathrm{mg} / \mathrm{mL}$, then dried at room temperature. The soaked disks were put down in Petri dishes inoculated with bacteria broth and the diameters of inhibition were read after incubation at $37^{\circ} \mathrm{C}$ for 18 to 24 hours.

\subsubsection{Antiparasitic research}

All assessments were led in the Laboratory of Antiparasitic Chemotherapy of the faculty of pharmacy of Châtenay-Malabry (France).

Trypanocide activity was studied, using GVR 35 (Glasgow Veterany Research) strain of Trypanosoma brucei brucei. The strain was maintained at a mouse by transplanting in syringe at least three days before the test. The parasites, got back by aseptic taking of the blood of the vein of the tail of a strongly infected mouse, were diluted in an adequate way by means of the culture medium to obtain 200000 trypomastigotes $/ \mathrm{mL}$. The circulating forms of the parasite were cultivated in vitro without loss of their infectious power, during 24 hours at $37{ }^{\circ} \mathrm{C}$ in an atmosphere of air containing $5 \% \mathrm{CO}_{2}$. The parasites were distributed in microplate of 96 wells of 200 $\mu \mathrm{L}$ at the rate of $2.10^{5} / \mathrm{mL}$. Then, $5 \mu \mathrm{L}$ of the adequate dilution of tested products (extract and melarsoprol as standard drug) in the DMSO, were added in triplicate. Wells control received only $5 \mu \mathrm{L}$ of solvent. After 24 hours of incubation, the viability of trypanosomes was estimated by direct observation in optical microscope.

Elephanticide activity was studied, using LV9 strain of Leishmania donovani. Leishmania's, at promastigote stadium, were maintained in culture in flasks of $25 \mathrm{~mL}$ containing $5 \mathrm{~mL}$ of RPMI medium. Tested products (extract and pentamidine as standard drug) were diluted at first in DMSO, then in RPMI to reduce the final concentration in solvent under $2 \%(\mathrm{v} / \mathrm{v})$ during the tests, such a percentage of DMSO not affecting the viability of the parasites. In each of 96 wells of the microplate, 195 $\mu \mathrm{L}$ of culture medium containing $2.10^{5}$ promastigotes were put down. The microplates were then placed in a steam room at $27{ }^{\circ} \mathrm{C}$ for 1 hour. After this incubation, 5 $\mu \mathrm{L}$ of tested substances were added in triplicate for 4 hours. The evaluation of elephanticide activity was realized by direct reading in optical microscope and by quantitative colorimetric dosage by MTT.

Caenorhabditis elegans strain assessed for anthelminthic activity was provided by Pasteur Institute. The experience was led according to method described by Ravina et al. [10]. The tests were realized in microplate of 24 wells, each well receiving $10-15$ parasites in $0.5 \mathrm{~mL}$. After 7 to 20 days of incubation with tested products (extract and mebendazole as standard drug), the optical density of each well was measured, by reading in binocular microscope. Thus, the percentage of motionless worms, considered as "dead" were determined.

\subsubsection{Antifungal research}

Strains of Aspergillus fumigatus and Candida albicans were provided by Pasteur Institute. A. fumigatus conidia were collected from a culture of 7 days in malt agar at $35^{\circ} \mathrm{C}$, then cleansed by centrifugation in $1500 \mathrm{rpm}$ and by washing with saline buffer containing $0.01 \%$ of Tween $20^{\circledR}$. For yeasts, cultures of 48 hours of $C$. albicans on Sabouraud Dextrose Agar were used. Both strains were studied in MOPS medium and the inhibition of fungi culture was measured by the method of dilution in broth.

\subsection{Statistical Method}

Values were expressed as percentage of inhibition. Data were analyzed with GraphPad Prism. $7^{\circledR}$ software by Wilcoxon statistical test, with criterion set for statistical significance at $\mathrm{p}<0.05$ for risk of $\alpha=0.05$.

\section{Results}

\subsection{Antibacterial Potential}

In the presence of increasing concentrations of the extract $(6.25 ; 25 ; 100$ and $200 \mathrm{mg} / \mathrm{mL})$, Staphylococcus aureus, Escherichia coli, Bacillus sp, Pseudomonas aeruginosa and Enterococcus faecalis grew whereas cefixime inhibited their growth (Figure $1 \&$ Table 1). MIC was not applicable (Table 2).

\subsection{Antiparasitic and Antifungal Potentials}

IC90 of the plant extract on Trypanosoma brucei brucei, Leishmania donovani, Caenorhabditis elegans, Aspergillus fumigatus and Candida albicans were higher than those of standard drugs (Table 3).

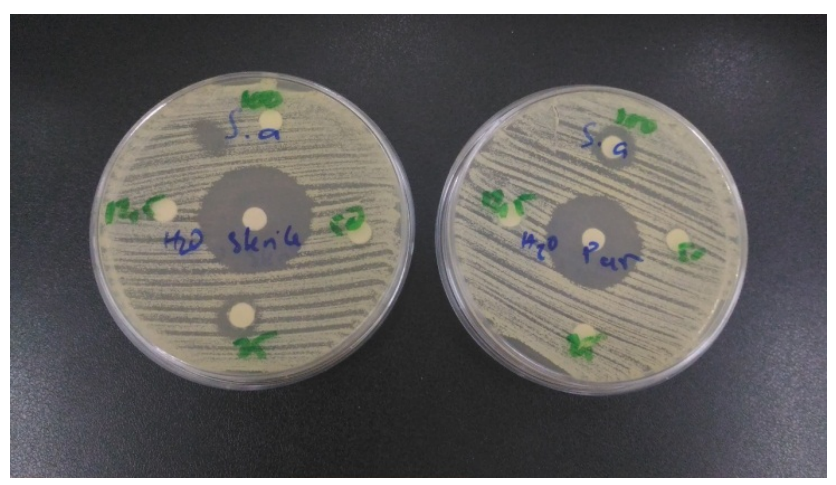

Figure 1. Aqueous-alcoholic extract after diffusion in Staphylococcus aureus Petri dishes with cefixime disk in the middle 
Table 1. Sensibility of bacteria to tested substances

\begin{tabular}{|c|c|c|c|c|c|}
\hline & \multicolumn{4}{|c|}{ Extract Concentrations (mg/mL) } & \multirow{2}{*}{$\begin{array}{c}\text { Cefixime }(\mathrm{mg} / \mathrm{mL}) \\
20\end{array}$} \\
\hline & 200 & 100 & 25 & 6.25 & \\
\hline E. coli & - & - & - & - & + \\
\hline P. aeruginosa & - & - & - & - & + \\
\hline Bacillus sp & - & - & - & - & + \\
\hline S. aureus & - & - & - & - & + \\
\hline E. faecalis & - & - & - & - & + \\
\hline
\end{tabular}

(-): Absence of antibacterial activity

$(+)$ : Presence of antibacterial activity

Table 2. Effect of extract dilutions on bacteria growth in microplate

\begin{tabular}{|c|c|c|c|c|c|c|}
\hline \multirow{2}{*}{} & \multicolumn{7}{|c|}{ Extract concentrations (mg/mL) } \\
\cline { 2 - 7 } & $\mathbf{1 0 0}$ & $\mathbf{5 0}$ & $\mathbf{2 5}$ & $\mathbf{1 2 . 5}$ & $\mathbf{6 . 2 5}$ & $\mathbf{3 . 1 2 5}$ \\
\hline E. coli & + & + & + & + & + & + \\
\hline P. aeruginosa & + & + & + & + & + & + \\
\hline Bacillus sp & + & + & + & + & + & + \\
\hline S. aureus & + & + & + & + & + & + \\
\hline E. faecalis & + & + & + & + & + & + \\
\hline
\end{tabular}

$(+)$ : Bacteria growth

Table 3. Effect of extract on parasites and fungi growth in microplate

\begin{tabular}{|c|c|c|c|c|c|}
\hline \multicolumn{7}{|c|}{ Inhibitive Concentration 90\% IC90 ( $\boldsymbol{M M})$} \\
\hline & T. brucei & L. donovani & C. elegans & C. albicans & A. fumigatus \\
\hline Extract & $>125$ & 40.5 & $>125$ & 62.5 & $>125$ \\
\hline Melarsoprol & 0,4 & & & & \\
\hline Pentamidine & & 7,7 & & & 0,064 \\
\hline Mebendazole & & & 2,6 & & \\
\hline Amphotericin B & & & & & \\
\hline
\end{tabular}

\section{Discussion}

The study's aim was to assess potential anti-infective effects of Dichrostachys cinerea root bark, an Ivorian folk herbal used to manage asthma. An aqueous-alcoholic extract of plant part did not exert antibacterial effect against bacteria very often found in the secondary infections of asthma, i.e. Staphylococcus aureus, Escherichia coli, Bacillus sp, Pseudomonas aeruginosa and Enterococcus faecalis. However, the plant is used in Sahel regions for the treatment of furunculosis, eczema and wounds [11]. Malinkés peoples (North of Côte d'Ivoire) also use the decoction of Dichrostachys cinerea roots to make mouthwashes in case of tooth decays [6], being able to be of infectious origin. Besides, according to Kambizi and Afolayan [12], this herbal is widely prescribed in traditional medicine of Zimbabwe for the treatment of sexually transmitted infections, the roots being the most used part of the plant. The absence of antibacterial activity in our study could be due to geographical regions or nature of ground. As a result, it was shown in Sudan that leaves of the plant possessed anti-infective activities [13]. Also, to heal circumcision wounds, Malinkés peoples use calcined aerial parts of the plant, in local applications [6]. According to the findings of Sinon [14], the leaves extracts of this plant would be active on bacterial strains among which, Staphylococus aureus, Streptococcus pyogenes and Pseudomonas aeruginosa. These antibacterial properties would be due to primary compounds of the whole plant, such as tannins $[9,15]$.

About parasites and fungi, the extract did not exert any effect on Trypanosoma brucei brucei, Caenorhabditis elegans and Aspergillus fumigatus, IC90 being superior to $125 \mu \mathrm{M}$. The extract exerted an effect on Leishmania donovani and Candida albicans, but not significant to be qualified as antiparasitic and antifungal properties (IC90 < $125 \mu \mathrm{M}$ but high comparatively to standard drugs). 
A previous study isolated alkaloid with pyrrolidine structure from the root bark of Dichrostachys cinerea [16], able to be important in exploration of other pharmacological properties. Indeed, drug molecules, such as some antimalarial ones have pyrrolidine structure.

\section{Conclusions}

Our study did not reveal antibacterial effect, neither antifungal nor antiparasitic activities, but the possibility of in vivo transformation of ammonium contained in the pyrrolidine structure of the root bark extract in quaternary ammonium opens perspectives of search for antimalarial activity.

\section{Acknowledgements}

We are very grateful to L. Aké-Assi and Assi J. (National Floristic Center of Abidjan, Côte d'Ivoire) for botanical identification, and P. Loiseau (UMR CNRS 8076 BioCIS, Châtenay-Malabry, France) for technical assistance.

\section{REFERENCES}

[1] F. Malaisse. La gestion des produits sauvages comestibles, Défis-Sud, Vol.7, 18-19, 1992.

[2] WHO. Résultats du projet ACDI/OMS-AFRO-questionnai re de la consultation de fin de projet rempli par les pays, 2012.

[3] Z. I. Kaboré, H. Millogo/Koné. Étude antibactérienne in vitro d'extraits alcalö̈diques de Holarrhena floribunda (Apocynaceae) vis-àvis d'Escherichia coli Entéropathogène, Sérotype 0127, Revue Pharmacopée et Médecine Traditionnelles Africaines, No.9, 17-23, 1997.

[4] C. Akoua-Koffi, N. Guessennd, V. Gbonon, A. Y. H. Faye-Kette, M. Dosso. Methicillin resistant of Staphylococcus aureus in Abidjan (1998-2001): a new hospital problem, Médecines et Maladies Infectieuses, Vol.34, 132-136, 2004.

[5] D. Guillemot, P. Maugendre, S. T. C. Vhauvin. Consommation des antibiotiques en France, BEH, Vol.3233, 141-147, 2004.
[6] E. J. Adjanohoun, L. Ake-Assi. Contribution au recensement des plantes medicinales de Côte d'Ivoire Centre national de floristique Abidjan, CRESS, Abidjan, 1979.

[7] G. Irie-N'guessan, P. Champy, G. Kouakou-Siransy, A. Koffi, B. J. Kablan, V. Leblais. Tracheal relaxation of five Ivorian anti-asthmatic plants: Role of epithelium and $\mathrm{K}^{+}$ channels in the effect of the aqueous-alcoholic extract of Dichrostachys cinerea root bark, Journal of Ethnopharmacology, Vol.138, No.2, 432-8, 2011.

[8] J. Bousquet, P. K. Jeffery, W. W. Busse, M. Johnson, A. M. Vignola. Asthma from bronchoconstriction to airways inflammation and remodeling, American Journal of Respiratory Critical Care Medicines, Vol.161, 1720-1745, 2000.

[9] A. G. Irié-N'guessan. Rôle des ions potassium et de l'épithélium dans la relaxation du muscle lisse trachéal : application à la propriété antispasmodique de cinq plantes antiasthmatiques issues de la pharmacopée ivoirienne, Thèse de Doctorat en Sciences Pharmaceutiques, Université Félix Houphouët-Boigny, 193 pages, 2013.

[10] M. Diaz-Ravina, M. J. Acea, T. Carballas. Seasonal fluctuations in microbial populations and available nutrients in forest soils, Biology and Fertility of Soils, Vol.16, 205-210, 1993.

[11] H. J. Von Maydell. Trees and Shrubs of the Sahel: Their Characteristics and Uses, Verlag Josef Margraf, Scientific Books, Germany, Vol.196, 1990.

[12] L. Kambizi, A. J. Afolayan. An ethnobotanical study of plants used for the treatment of sexually transmitted diseases (njovhera) in Guruve District, Zimbabwe, Journal of Ethnopharmacology, Vol.77, No.1, 5-9, 2001.

[13] M. M. Eisa, A. Z. Almagboul, M. E. A. Omer, A. A Elegami. Antibacterial activity of Dichrostachys cinerea, Fitoterapia, Vol.71, No.3, 324-327, 2000.

[14] L. Sinon. Contribution à l'étude de l'activité antibactérienne des extraits des feuilles de Dichrostachys cinerea (L.) Wight \& Arn. (Mimosaceae), Thèse de pharmacie, Université de Ouagadougou, 79 pages, 2001.

[15] A. Banso, S. O. Adeyemo. Evaluation of antibacterial properties of tannins isolated from Dichrostachys cinerea, African Journal of Biotechnology, Vol.6, No.15, 1785-1787, 2007.

[16] J. M. E. Dade, G. Irie-N'Guessan, G. Komlaga, M. Say, T. A. Okpekon, J. B. Boti, B. J. Kablan, E. H. S. Bamba. Pyrrolidine alkaloids and their glycosylated derivatives from the root bark of Dichrostachys cinerea (L) Wight \& Arn. (Fabaceae), Phytochemistry Letters, Vol.16, 268-276, 2016. 